\title{
Radiological Assessment of Epiphora by Dacryocystography
}

\section{Hara M. ${ }^{1}$, Parashar H. ${ }^{2}$}

${ }^{1}$ Dr. Mamta Hara, Junior Specialist, ${ }^{2}$ Dr. Hemendra Parashar, Medical Officer; both authors are affiliated with SRG Hospital \& Medical College Jhalawarrajasthan.

Address for Correspondence: Email id: ashwani.rathade@gmail.com

\begin{abstract}
Objectives- To find out various causes of epiphora, level and type of block in lacrimal passage, lacrimal pump function, causes of failed dacryocystorhinostomy. Materials and Methods- Dacryocystographywas done in 100 eyes of 83 patients of epiphora and divided in three groups, Epiphora with patent lacrimal system, non patent lacrimal system, and residual epiphora after the operation of dacryocystorhinostomy. Dacryocystography was performed by using $0.5-1 \mathrm{ml}$ of urograffin $76 \%$ with the lacrimal cannula and X-ray during forceful injection of the dye. A-P lateral \& PNS waters view (magnified) were taken by 500 na X-ray Machine. Results- Incidence of epiphora was 41\% Right eye, 39\% Left eye, $20 \%$ both eyes. Male female ratio, 16:84. All age groups are affected almost equally with slight higher incidence in $6^{\text {th }}$ decade in female. On the basis ofdacryocystography, Complete block in $60 \%$ cases, partial block in $9 \%$ cases, and no block was observed in 31\% cases. Level of block was at Canalicular in 3\%, at common canalicular in $7 \%$, at lacrimal sac-duct junction in $84 \%$ and at lower end of nasolacrimal duct in $6 \%$ of cases. Prevalence of associated ENT disorders about in $24 \%$ and atonic sac in 4 cases. Conclusions- Dacryocystography isa simple, easy, cheap, safe and less time consuming investigation, which can be done even at most peripheral level of health services where X-ray facilities are available.
\end{abstract}

Keywords: Atonic sac, Dacryocystography, Dacryocystorhinostomy, Epiphora, Urograffin

\section{Introduction}

Epiphora or excessive drainage ofwater from the eye is almost a universal symptom of disease of lacrimal passage resulting due to improper drainage of tears. It is a very common condition in our rural setup due to unhygienic living conditions illiteracy, poverty, and ignorance and poor infrastructure of health services.

Epiphora due to the lacrimal puncta are misplaced or absent, the lacrimal passage is blocked by atresia, trauma, foreign body or neoplasm. The nose may be obstructed by nasal polyp extreme deviation of nasal septum or inferior turbinate hypertrophy. The Lacrimal pump failure. Adequate assessment of epiphorais necessary for diagnosis \& management by syringing \& probing of lacrimal passage and dacryocystography

\section{Aims and Objectives}

This prospective study has been done with the idea of evaluating \& establishing the usefulness of dacryocystography in patients with epiphora for an

Manuscript received: $4^{\text {th }}$ May 2017

Reviewed: $14^{\text {th }}$ May 2017

Author Corrected; $20^{\text {th }}$ May 2017

Accepted for Publication: 24 $4^{\text {th }}$ May 2017 ophthalmologist to properly plan out the management. To find out various causes of epiphora, level andtype of block in lacrimal passage, lacrimal pump function, causes of failed dacryocystorhinostomy.

\section{Material \& Method}

The present study was conducted in Department of Ophthalmology in found collaboration of Department of Radiodiagnosis, SRG Hospital \& Medical College Jhalawar During 2016 to 2017. 100 eyes of 83 patients complaining of epiphora were selected for dacryocystography and divided in the following groups

1- Epiphora with patent lacrimal system

2- Epiphora with non patent lacrimal system

3- Case of residual epiphora after the operation of dacryocystorhinostomy.

Patients with acute or sub acute inflammation were excluded. The $24 \mathrm{G}$ cannual is introduced in punctum. A $30 \mathrm{~cm}$ long catheter attached with a $10 \mathrm{cc}$ syringe, is connected to the lacrimal cannula with $0.5-1 \mathrm{ml}$ of urograffin $76 \%$ is injected. X-ray exposures are mad during forceful injection of the dye. A-P lateral \& PNS 


\section{Original Research Article}

waters view (magnified) were taken by 500 na X-ray Machine. On basis of Radiological criteria of abnormal Dacryocystography Level of Block

1- Canalicular block

2- Common Canalicular block

3- Block at sac-duct junction

4- Blocks at lower end of nasolacrimal duct

5- No apparent abnormality

\section{Observation}
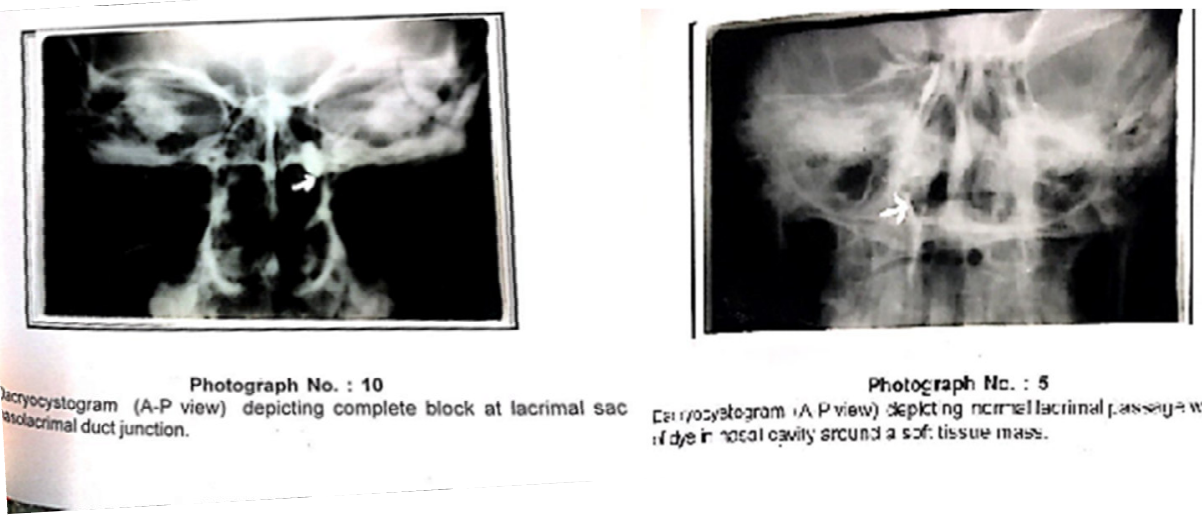

On the basis of dacryocystorgraphy findings 46 cases were subjected to dacryocystorhinostomy operation.

For clinical correlation of findings of dacryocystography, methylene blue dye was injected in lacrimal passage on operation table \& findings were correlated by direct visualization.

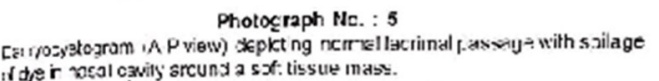
d de ir nosl cowily arcunda saf: tissue miss.
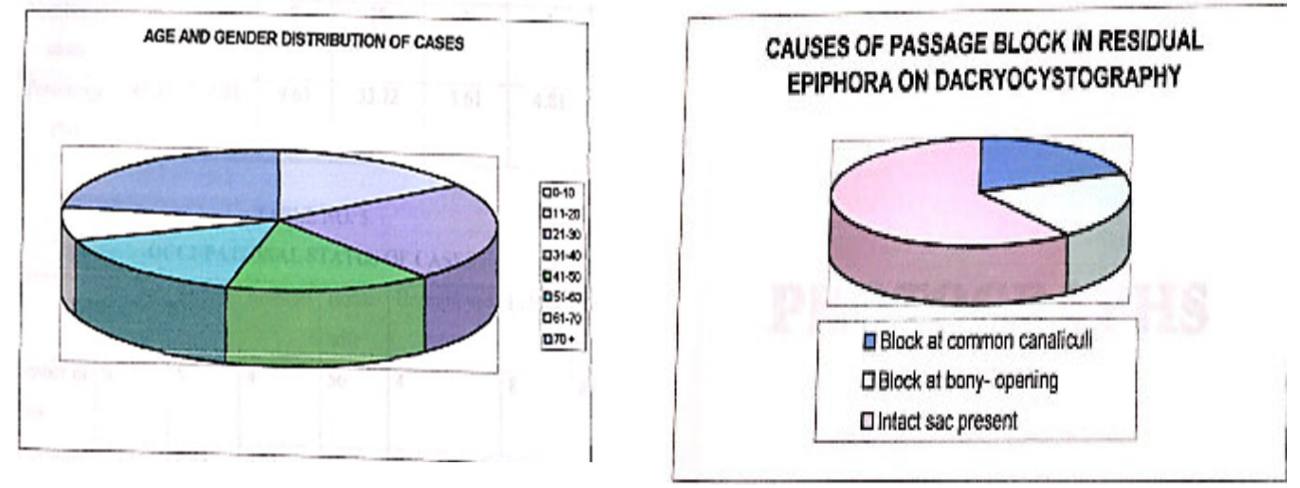

Prevalence of Associated ENT Diseases

\begin{tabular}{|c|c|c|}
\hline ENT disease & No. of cases & Percentage (\%) \\
\hline DEVIATED Nasal Septum & 3 & 3.61 \\
\hline Inferior Turbinate Hypertrophy & 4 & 4.81 \\
\hline Deviated Nasal Septum with Inferior Turbinate Hypertrophy & 3 & 3.61 \\
\hline Chronic Rhinitis & 2 & 1.21 \\
\hline Rhinosporiodosis & 1 & 2.42 \\
\hline Congestion of nasal mucosa & 2 & 3.61 \\
\hline Sinusitis & 3 & 1.21 \\
\hline Atrophic Rhinitis & 1 & 1.21 \\
\hline Suppurative Otitis Media with myringitis & 1 & 75.92 \\
\hline AND & $\mathbf{1 0 0}$ \\
\hline Total & $\mathbf{8 3}$ & \\
\hline
\end{tabular}


Level of block

\begin{tabular}{|c|c|c|}
\hline Canalicular Block & 1 & $2.91 \%$ \\
\hline Common Canalicular block & 5 & $7.22 \%$ \\
\hline Sac duct junction block & 58 & $84.05 \%$ \\
\hline Block in nasolacrimal duct & 2 & $2.91 \%$ \\
\hline Block of bony-opening & 2 & $2.91 \%$ \\
\hline Total & $\mathbf{6 9}$ & $\mathbf{1 0 0 \%}$ \\
\hline
\end{tabular}

\section{Discussion}

The lacrimal fluid flows over the preocular surface \& reaches the marginal tear strip running along the margin of each eyelid \& collects as lacuslacrimalis near inner canthus. From the lacuslacrimalis\& along the marginal tear strip the lacrimal fluid is then drained by the lacrimal passage through the punctum by capillary action.

Then by the active lacrimal pump mechanism constituted by fiberes of the preseptal portion of the orbicularis. The lacrimal pump pushes the fluid into the nasolacrimal duct with the blinking movements of the eyelids.

Right eye involvements was observed in $41 \%$ Left eye involvement in 39\% 20\% cases had epiphora in both eyes. Male: Female ration was 16:84.

All age groups are affected almost equally with slight higher incidence in $6^{\text {th }}$ decade in female where ists $27 \%$ $\&$ also $3^{\text {rd }}$ decade in Males where its $23 \%$ the difference may be due to the fact that only certain specific infection are more common in males, Whereas females in general may suffer from chronic irritation leading to chronic dacryocystitis such as caused by smoke etc. while cooking or doing other household work 5.Poor socio-economic status was observed in $92 \%$ of cases. 6

Type of Blocks- In this study complete block in the lacrimal passage was observed in $60 \%$ cases. Whereas $9 \%$ cases had partial block. No block was observed in $31 \%$ cases due to some inflammatory changes in lacrimal passage in majority of such cases.

Level of Block- Canalicular block in 3\% cases, common canalicular block in $7 \%$ cases, block at lacrimal sac-duct junction in $84 \%$ and lower end of nasolacrimal duct in $6 \%$ of cases. 5 We have done dacryocystography in 13 cases of residual epiphora, out of which we found block in 10 cases Out of these cases we observed sommon canalicular block in $20 \%$ cases block of bony passage in $20 \%$ cases \& intact sac was present in $60 \&$ cases.

This clearly shows that most common cause of residual epiphora was due to making and suturing of false flaps of muscular layer or lamellar sac flap i.e. improper sac flaps. Prevalence of associated ENT disorders about in $24 \%$ of cases of epiphora.

These included deviated nasal septum, inferior turbinate hypertrophy, deviated nasal septum with inferior turbinate hypertrophy, chornic rhinitis and sinusits. We observed atonic sac in 4 cases.

\section{Summary and Conclusion}

We have found dacryocystography to be a simple, easy, cheap, safe and less time consuming investigation which can be done even at most peripheral level of health services where X-ray facilities are available.

It is most informative in relation to localizing exact level of block and associated pathology as compared to other sophisticated investigations which require modern high technology that happen to be very costly and not easily available in most parts of our country dacryocy stographyalos does not lead to any complication or after effects.

\section{Funding: Nil, Conflict of interest: None. Permission of IRB: Yes}

\section{References}

1. Ewing A.E/ "Roentgen Ray demonstrations of the lacrimal abscess cavity America Jouranal of Ophthmology, 1909:26:1 


\section{Original Research Article}

2. Agrawal M.L. Dacryocystography in chronic dacryocystitis. American Jouranal of Opththalmology 1961: 52.245

3. Bansal R.K. Jain A.L Om Prakash "Dacryocystography in normal lacrimal drainage system "Indian journal of Radilogy, 1970:163.
4. Campbell William "The Radiology of lacrimal system "British Journal of Radiology, 1964:37:1

5.Nahata M.C: "Dacryocystography in diseases of lacrimal sac" American Journal of Ophthamology, 1964:58:490.

\section{How to cite this article?}

Hara M, Parashar H. Radiological Assessment of Epiphora by Dacryocystography. Trop J Ophthalmol Otolaryngol.2017;2(1):10-13. doi: 10.17511/jooo.2017.i01.03. 